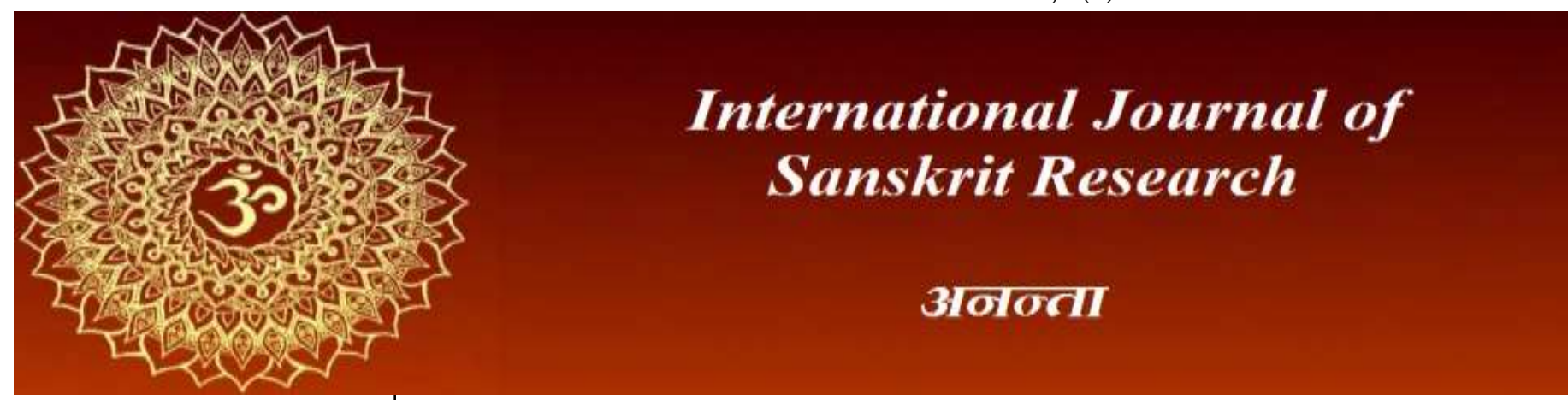

ISSN: 2394-7519

IJSR 2021; 7(5): 249-254

(C) 2021 IJSR

www.anantaajournal.com

Received: 12-07-2021

Accepted: 03-08-2021

\section{Bhagyashree Sarma}

Research Scholar, Sanskrit

Department, Gauahti

University, Guwahati, Assam,

India

Sudeshna Bhattacharjya

Professor, Sanskrit Department,

Gauahti University, Guwahati,

Assam, India
Corresponding Author: Bhagyashree Sarma

Research Scholar, Sanskrit

Department, Gauahti

University, Guwahati, Assam,

India

\section{Single hand gestures in the Viṣnudharmottarapurāna and the Abhinayadarpana: A comparative study}

\author{
Bhagyashree Sarma and Sudeshna Bhattacharjya
}

\begin{abstract}
:
Indian classical Dances contain different elements through which a Dance form can be presented gracefully. The gestures and postures of Indian classical dances are very particular as in every classical dance form; the views of ancient scriptures on Dance seem to be followed. The Nätyaśâstra is regarded as the most authentic work on Dance and Drama. The Viṣnudharmottarapurāna as well as the Abhinayadarpana also seem to follow the path of the Nätyaśästra as both of these works talk about different elements of Indian classical Dances. But in some context, different point of views of these two works also can be noticed as both have their own perspectives and practices. Asamyuktahastas i.e. single hand gestures are the most integral element of Indian classical Dances, through which the dancers can project a concept in front of the audience with the help of hand gestures. So, in this present paper an attempt has been made to highlight a comparative study between the Viṣnudharmottarapurāna and the Abhinayadarpana regarding the context of Asamyuktahastas i.e. single hand gestures.
\end{abstract}

Keyword: Dance, single hand gesture, Viṣnudharmottarapurāṇa, Abhinayadarpaṇa

\section{Introduction}

Dance is a variety of performing art which is exercised in a graceful way through bodily movements, gestures, expressions, sentiments, rhythm and songs. It is the beautiful way to express the inner feelings of a person. It is also a mode to conceptualise any idea before the viewers. It can be termed as a mediator between an artist and the spectator. It is important to note here that, in this mode of expression, the gestures and postures are the only way to convey the meaning. So, the exact and flawless projection of each gestures and postures in Dance is very important. The hand gestures and postures possess great important in this context. In Dance, the hands are used as the communicative medium to convey the story. In the Abhinayadarpana, Nandikesvara states that the hands are used to express the meaning [1]. Moreover, it expresses the imagination and the creative power of the performer. So, it can be said that the proper execution of hand gestures and hand postures are very important in any kind of Dance form.

The discussion about different kind of hand gestures and postures are found in different ancient treatises viz., the Nātyaśāstra, the Abhinayadarpaṇa, the Śrīhastamuktāvali etc. Moreover, the Viṣnudharmottarapurạna is also seen to have a detail discussion in this context. In the Viṣnudharmottarapurāna, the hastamudrās i.e. hand gestures are divided into three groups. These are: asamyuktahasta, samyuktahasta and nrttahasta. In this context the Viṣnudharmottarapurāṇa seems to follow the Nātyaśāstra as the Nātyaśāstra also admits these three varieties of hand gestures ${ }^{[2]}$. But the Abhinayadarpana mainly accepts two groups of hand gestures viz. asamyuktahasta and samyuktahasta ${ }^{[3]}$. The reference of the variety called nrttahasta is not found in the Abhinayadarpana. Not only in the context of groups of hand gestures but also in the perspective of numbers of hand gestures, their formations, implementations etc.

\footnotetext{
${ }^{1}$ hastenārtham pradarśayet/ Abhinayadarpana, 36

${ }^{2}$ Nātyaśāstra, 9. 4-10

${ }^{3}$ asaminuktāḥ samyuktāśca hastadvedhā nirūpitā/ Abhinayadarpaṇa, 88
} 
the view points of the Viṣnudharmottarapurāna shows a number of differences from the narration and guideline found in the Abhinayadarpana. On the other hand, in some context, these two works are seen to keep their views in a similar manner. So, a comparative study between these two works regarding the context of single hand gestures shows its demand. Thus the concept of present paper has been conceived. The aim of this paper is to analyse the materials available in both these sources and then to bring out a comparative note as the topic of discussion.

\section{A comparative study between the Viṣnudharmottarapurāna and the Abhinayadarpana regarding the single hand gestures and postures:}

The term Asamyukta denotes that which is not connected ${ }^{[4]}$. Asamyuktahastas are the dancing postures made only by single hand. So, it may be called single hand gestures. In the Viṣnudharmottarapurāṇa, twenty two kinds of asamyuktahastas are mentioned. These are- patāka, tripatāka, kartarīmukha, ardhacandra, arāla, śukatuṇda, muști, śīkhara, kapittha, khațakāmukha, sūcīmukha, padmakośa, ahiśīrșa, mrgaśīsșa, kāngūla, kola-padma, catura, bhramara, hamsavaktra, hamisapakșa, sandamiśa and mukula ${ }^{[5]}$. But in the Abhinayadarpana twenty eight kinds of hand gestures are accepted [6]. The hastamudrās viz. ardhapatāka, mayūra, candrakalā, simhamukha, tāmracūda and triśula are absent in the Viṣnudharmottarapurāna where as the Abhinayadarpaṇa accepts these varieties. The Nātyaśāstra accepts twenty four kinds of single hand gestures [ 7 ]. In the Viṣnudharmottarapurāna, these twenty two types of single hand gestures and their applications in Dance are elaborately explained. The study of these will give a clear picture on the present idea.

i) Patāka: The word patāka denotes dhvajam in Sanskrit which means flag or banner [ $\left.\begin{array}{lll}8 & ]\end{array}\right]$ But in the Śabdakalpadruma, the term patāka is found, which denotes the similar meaning with patāka i.e. dhvajam ${ }^{[9]}$. According to Abhinavagupta this hand posture looks like a flag and that is why it is named as patāka ${ }^{[10]}$. In patākahasta, all the fingers are straightened and the thumb is bent [ 11 ]. According to the Viṣnudharmottarapurāna, to show the blowing of wind and raining, the patākahasta is used in Dance [12]. Moreover, the dancer uses the patākahasta to show the acting to take and obstruct prahāra i.e. stike or beat ${ }^{[13]}$ in a Dance performance ${ }^{[14]}$. So, it can be assumed that this posture denotes an obstruction in a dance performance. But the Abhinayadarpana does not suggest to use the patākahasta in obstruction. Instead of it, the Abhinayadarpana says that the patakkahasta is used to denote the beginning of a drama ${ }^{[15]}$. Moreover, this hand

\footnotetext{
${ }^{4}$ asamyutā natvete saṁyutā eva/ Abhinavabhāratī commentary, Nātyaśāstra, Pushpendra Kumar (ed), p.363

${ }^{5}$ Viṣnudharmottarapurāna $3.26 .1-3$

${ }^{6}$ Abhinayadarpana,81-92

${ }^{7}$ Nātyaśāstra,9.4-7

${ }^{8}$ M. Monier Williams, A Sanskrit-English Dictionary, p. 848

${ }^{9}$ Śabdakalpadruma, p.22

${ }^{10}$ patākākāratvātpatākaḥ/ ataeva patākāpyanenaivābhineyā/ Abhinavabhāratī,

Pushpendra Kumar (ed), Nātyaśāstra, Bharatmuṇi, Vol 1, p.343

${ }^{11}$ prasāritāgrā sahitā yasyānngulyo bhavanti hi/

kuñcitaśca tathāngușṭhaḥ sa patāka iti smṛtaḥ// Viṣnudharmottarapurāṇa,

3.26 .14

12 patāka....vāyuvrșțininūpaṇe// Viṣnudharmottarapurāṇa, 3.26.15

${ }^{13}$ V.S Apte, The student's Sanskrit English Dictionary, p.373

${ }^{14}$ patāka... eșa prahāragrahaṇe rodhane.../ Viṣ̣nudharmottarapurāṇa, 3.26 .15

${ }^{15}$ patākakaraḥ.... nāṭāambehe/ Abhinayadarpaṇa, 94
}

posture is used to symbolise some natural phenomenon like cloud, forest, bosom, river, wind etc ${ }^{[16]}$.

ii) Tripatāka: The word tripatāka itself identifies the importance of the number three. This hand posture is known as tripatāka because in this posture, three fingers should be straightened in a patākahasta where the ring finger is bent [17]. Abhinavagupta also keeps his view point in the same way ${ }^{[18]}$. This posture is used to denote some activities like calling a person, putting crown on head, showing small birds, wiping off tears, giving auspicious touch by putting on head, covering ears, lying on ground, movements of serpent and bees etc. [19] Instead of it, the Abhinayadarpana suggests that- the tripatāka hand is used to denote some objects like crown, tree, the ketaki flower, lamp etc. ${ }^{[20]}$ Indra along with his weapon i.e. vajra is also established with this hand posture in Dance. This hand posture shows the action of writing letters ${ }^{[21]}$.

iii) Kartarīmukha: The word kartarī means scissor ${ }^{[22]}$ and along with the word mukha, it means mouth of the scissor. The Viṣnudharmottarapurāna suggests that in the kartarimukhahasta, the hand should be in tripatākahasta posture and the fore-finger is kept in the back of the middle finger. In this posture, the fore-finger should not touch the middle finger ${ }^{[23]}$. When the fore-finger is kept in the back of the middle finger and when it does not touch the middle finger, it looks like the mouth of a scissor. But the view point of the Abhinayadarpana is totally different from the Viṣnudharmottarapurāna in this regard. According to the Abhinayadarpana, only two fingers i.e. fore-finger and the ring finger should be spread and straightened in kartarimukhahasta ${ }^{\text {[24] }}$ and rest of the fingers should be bent. So, it can be said that, according to the Abhinayadarpana, the middle finger is bent in kartarimukhahasta where as in the Viṣnudharmottarapurāna, it is completely straightened. Some activities like travelling, cutting and falling are executed with this hand gesture ${ }^{[25]}$.

iv) Ardhacandra: The derivation of the word ardhacandra is found in the Śabdakalpadruma as- ardham candrasya, candrakhandaim [ 26$]$ which means half of moon. Viṣnudharmottarapurāna suggests that in ardhacandrahasta, the ring finger touches the thumb ${ }^{[27]}$. From the name it appears that the form of the hand

\footnotetext{
${ }^{16}$ Abhinayadarpana, 95-100

${ }^{17}$ asyaikānāmikā vakrā tripatākā tathā bhavet/ Viṣnudharmottarapurāṇa, 3.26.17

18 anāmikā vakrā kanīyasītarjanīmadhyamānām tisțṇām patākavadvasthānāt tripatākaḥ tritvasyābhineyādvā/ Abhinavabhāratī, Pushpendra Kumar (ed.), Nātyaśāstra, Bharatmuni, Vol 1, p.346

19 āvāhane prayuñjīta mukuțābhinaye'pyuta/ laghupakșinirūpaṇe/ tayānāsikayā kāryam̉ tathaivāśrupramārjanam / mañgalasparśanam̉ kāryam śirasaśca niveśanam/

śrotrasaṁvarạ̣am் caiva kāryam̉ bhūmimukhena tu/ bhujaṅgānāmabhinayam bhramarān̄ām tathaiva ca/Vișnudharmottarapurāṇa, 3.26.18-20

${ }^{20}$ tripatākah.... makuțe vṛkṣabhāveșu....ketakīkusume dīpe.../

Abhinayadarpana, 101

${ }^{21}$ tripatākah vajre taddharavāsave/ patralekhāyām...Abhinayadarpaṇa, 101102

${ }^{22}$ V.S Apte, The student's Sanskrit English Dictionary, p.136

${ }^{23}$ tripatākā yadā haste bhavetprșțhāvalokin̄̄/ tarjanī tu tadā jñeyaḥ

kartarīmukhasamjjñakah/ Viṣnudharmottarapurāna, 3.26.21

${ }^{24}$ hastasya tarjanī ca kanișțhikā/bahị prasārite dve ca sa karah

kartarīmukhah/ Abhinayadarpaṇa, 105

${ }^{25}$ kāryo'yam parivahaneșu bhinnaśca pataneșu ca/ Viṣnudharmottarapurāṇa,

3.26 .22

${ }^{26}$ Śabdakalpadruma, p.106

${ }^{27}$ anāmikā tu sānnguṣthā ardhacandre kare bhavet/ Viṣnudharmottarapurāṇa, 3.26 .22
} 
should look like a part of the moon. But according to the Abhinayadarpana, if the bent thumb of patāka hand is stretched out, it is called ardhacandrahasta ${ }^{[28]}$. The point to be noted here is that, patāka hand with strengthened thumb looks like a half moon which justifies the hastamudrā called ardhacandra. But ardhacandra hand as narrated in the Viṣnudharmottarapurāna does not identify the hand posture which denotes half moon. In spite of it the posture of ardhacandrahasta, as stated in the Viṣnudharmottarapurāna is similar with the mayurahasta as found in the Abhinayadarpana [29]. According to the Viṣnudharmottarapurāna the ardhacandrahasta is used to show growing moon [30]. Moreover, it also identifies a child, the waist part of a person etc. The acting of putting ear-rings is also showed with this hastamudra ${ }^{[31]}$.

v) Arāla: The word arāla means which is bent or crooked ${ }^{[32]}$. According to the Viṣnudharmottarapurāna, the forefinger is slightly bent like a bow. The thumb is bent in this hand posture and the remaining fingers are strengthened and slightly curved ${ }^{[33]}$. This posture shows some concepts like deepness, entity, heroism etc. With the help of this posture, the dancer can do the acting of assembling hair and wiping of sweat [34]. But, in the Abhinayadarpana, the arāla posture is said to be used in the acting of drinking poison, nectar etc. Moreover, to show the heavy storm, this posture is suggested to be used in Dance ${ }^{[35]}$.

vi) Śkatunda: The word śukatunda is the amalgamation of two words viz., śuka and tunḍ. Śuka means parrot [36] and tunda means mouth [37]. So, the word śukatunda denotes the mouth or a beak of a parrot. In the Viṣnudharmottarapurāna, it is stated that the ring finger is bent in the position of arālahasta to make the śukatundahasta ${ }^{[38]}$. When the fore-finger and the ring finger are curved in arälahasta, the two bending fingers make a shape of a curve which looks like the beak of a parrot. Thus it justifies the name of this hand posture. According to the Viṣnudharmottarapurāna, with this posture, one can deliver the speech as "I am not you" [39]. The Nätyaśāstra also gives its viewpoint in the same spirit ${ }^{[40]}$. But in the Abhinayadarpana, this hand posture is said to be used in shooting of an arrow or a spear. Moreover, it is used to do the acting of recollecting home or the violent mood ${ }^{[41]}$.

\footnotetext{
${ }^{28}$ ardhacandrakarah so'yam patāke'ngușțhaprasāraṇāt/ Abhinayadarpaṇa, 111.

${ }^{29}$ asminanāmikāṅguṣṭhau ślișțau cānyāḥ prasāritāḥ/mayūrahastạ̣ kathitaḥ...// Abhinayadarpana, 108.

${ }^{30}$ ardhacandre kare...bālacandrābhinayane/ Viṣnudharmottarapurāṇa, 3.26.23

${ }^{31}$ ardhacandre kare...bālasyāttaravastathā/ mekhalām jaghanam̉ caiva

kuryāccānena kuṇụalam/ Viṣnudharmottarapurāṇa, 3.26.23

${ }^{32}$ Śabdakalpadruma, p.84

${ }^{33}$ khañḍapradeśinī kāryā angulyaḥ kuñcitāstathā/ śeșā bhinnordhvavalitā mrarālengulayạ̣ kare// Viṣnudharmottarapurāṇa, 3.26.24

${ }^{34}$ gāmbhīryasatvaśaumị̣īryakeśasamigrahaṇādiṣu/ svedasya cāpanayane śeșe caiṣa karo bhavet// Viṣnudharmottarapurāṇa, 3.26.25

35 ......arālakaḥ/ viṣādyamṛtapāneṣu pracaṇḍapavane'pi ca//

Abhinayadarpana, 114

${ }^{36}$ V.S Apte, The student's Sanskrit English Dictionary, p.558

${ }^{37}$ tuṇdam mukham்/ Śabdakalpadruma, p.632

38 arālạ̣ śukatuṇụaśca vakritānāmikānnguliḥ/ Viṣnudharmottarapurāṇa,

3.26 .26

${ }^{39}$ nāhantvamityathaitena nityam cābhinayed budhaḥ//

Viṣnudharmottarapurāna, 3.26.26

${ }^{40}$ nāham na tvam n kṛtyamiti cārthe/ Nātyaśāstra, 9.53

${ }^{41}$ bānaprayoge kuntārthe vā','layasya smritikrame/

ugrabhāveșu śukatuṇ̣̣o niyujyate// Abhinayadarpaṇa,115-116
}

vii) Muști: The word muști denotes the clenched hand [42]. According to the Viṣnudharmottarapurāṇa, in muști posture, the fingers bent towards the palm and the thumb is set on them ${ }^{[43]}$. This hand posture is used in activities like striking, practicing exercise, hardly pressing the breast, holding sword, stick and spear etc. ${ }^{[44]}$ In the Abhinayadarpana also, the muști posture is said to be used in holding things. To do the fight with hand this posture is adopted ${ }^{[45]}$. In the Śabdakalpadruma also, we find the meaning of the word muști as a technique of prahāra ${ }^{[46]}$.

viii) Śikhara: The word sikhara means the peak of a mountain [47]. This posture with this name tries to resemble the peak of a mountain. In sikharahasta, the thumb is lifted in the position of a fist ${ }^{[48]}$. This posture is used to hold rein, goad and bow ${ }^{[49]}$. According to the Nātyaśāstra, apart from holding rein, goad and bow, this posture is used to represent the acting of painting of the lips and feet. Moreover, to show the raising up of hairs, this posture is adopted in performance [50]. But according to the Abhinayadarpana, this posture is used for offering oblations, questioning, saying 'no', recollection, pulling at the girdle, the act of embrace and sounding a bell ${ }^{[51]}$.

ix) Kapittha: In the Śabdakalpadruma, the word kapittha is explained as a kind of tree where kapi i.e. monkeys stay due to the greed of fruit ${ }^{[52]}$. Moreover, the word kapittha denotes the fruit viz., wood apple [53]. According to Abhinavagupta, as the posture brings the shape of a wood apple, it is named as kapittha ${ }^{[54]}$. In kapitthahasta, the thumb is inside the fist ${ }^{[55]}$. The Abhinayadarpana defines this posture as when the fore-finger is bent over the top of the thumb in the síkharahasta, the posture is called kapitthahasta ${ }^{[56]}$. This posture is used to hold a disc or an arrow ${ }^{[57]}$.

x) Khatakämukha: The word khațakāmukha is an amalgamation of two words khataka and mukha. The word khataka denotes a half closed hand ${ }^{[58]}$ and mukha means mouth ${ }^{[59]}$. The term mukha also denotes beginning as it is used in the usage of mukhasandhi. According to

\footnotetext{
${ }^{42}$ V.S Apte, The student's Sanskrit English Dictionary, p.443

${ }^{43}$ anggulyo yasya hastasya talamadhye'grasaminthitāḥ/

tāsāmuparitāngușțhạ̣ sa mușțiriti samjuñitaḥ/ Viṣnudharmottarapurāṇa,

3.26.27

${ }^{44}$ eșa prahāre vyāyāme nirdayastanapị̣̄ane / sandhāraṇe'siyaṣtyośca grahạ̣e

kuntadaṇdayoḥ// Viṣnudharmottarapurāṇa, 3.26.28

${ }^{45}$ vastvādīnām ca dhāraṇe/ mallānām yudhabhāve'pi muștihasto'yamișyate//

Abhinayadarpana, 117.

${ }^{46}$ mușți prahāraviśeșaḥ/ p.753

${ }^{47}$ śikhara, parvatāgram், śṛngam/ Śabdakalpadruma, p.71

48 urdhvāngușțho'yameva syātkaraḥ śikharasamjjñiteḥ/

Vișnudharmottarapurāna, 3.26.29

49 eșa raśmigrahe kāryaścāpānnkuśadhanurgrahe// Viṣnudharmottarapurāṇa, 3.26 .29

${ }^{50}$ adharoșțapādarañjanamalakasyotkșepaṇam caiva/ Nātyaśāstra, 9.57

${ }^{51}$ śikharạ̣ karah....pitṛkarmaṇi prașṇabhāंvane/ nāstīti vacane smaraṇe'bhinayāntike/ kațibandhākarșaṇe ca parirambhavidhikrame/

ghaṇtānināde śikharo yujyate../ Abhinayadarpaṇa, 119-120

${ }_{52}$ kapitthah kapiḥ tișțhati phalapriyatvāt lobhāt vā yatra/ Śabdakalpadruma, p.23

${ }^{53}$ V.S Apte, The student's Sanskrit English Dictionary, p.132

${ }^{54}$ kapitthākāre'smin añgușțhatarjanyāvañgulī/ Abhinavabhāratī, Pushpendra

Kumar (ed), Nātyaśāstra, Bharatmuṇi, Vol 1, p.352

${ }_{55}$ muștimadhyagatongguṣthah kapittha iti kīrtitạ̣/ Viṣnudharmottarapurāna, 3.26 .30

${ }^{56}$ aṅgușthamūrdhniśikhare vakritā yadi tarjan̄̄ / kapitthākhyạ̣ karạ̣....// Abhinayadarpana, 121

${ }^{57}$ anenābhinayaḥ kāryo madhye cakre śare tathā/ Viṣnudharmottarapurāṇa, 3.26 .30

${ }^{58}$ khațakaḥ kuñcitapāṇị̣/ Śabdakalpadruma, p.271

${ }^{59}$ V.S Apte, The student's Sanskrit English Dictionary, p. 441
} 
the Viṣ̣udharmottarapurāṇa in khațakāmukhahasta, the thumb is inside the fist and the ring finger and the small finger are lifted and bent ${ }^{[60]}$. This posture is used to denote sacrifice, holding of an umbrella or a garland or rope, dragging and fanning [61]. Apart from holding a garland and necklace, the Abhinayadarpana also suggests the use of this posture to show the activities like picking flowers, offering betel leaves, preparing paste, applying perfumes etc. ${ }^{[62]}$

xi) Sūcīmukha: The word $s \bar{u} c \bar{l}$ means a tool which is used for stitching [63]. It is nothing but the needle. In sūcimukha posture, the fore-finger is extended in khatakämukha mudra [64]. When the fore-finger is extended and placed in the present posture, it looks like pointing to something with the fore-finger. Needle is also pointed. Thus to comes the origin of the name. The natural phenomenon like day and night are denoted with this hand posture. It is also used to denote the eyes of Śakra and Maheśa [65]. Śakra denotes Indra [66] and Maheśa denotes lord Śiva [ 67 ]. But in the Abhinayadarpana, the numbers like one and hundred are shown with this posture. Paramabrahma i.e. the Supreme Spirit is also indicated with this hand posture. Moreover, this hand posture also indicates the sun and the world ${ }^{[68]}$. The Point to be noted here is that- the thing or concept, which are indicated with this hand posture are generally distinct and unique in this world.

xii) Padmakośa: The word padmakośa means the calyx of a lotus ${ }^{[69]}$. According to the Viṣnudharmottarapurāna, the top of all fingers are brought together in padmakośahasta and it looks like the nails of a swan ${ }^{[70]}$. In this regard the Viṣnudharmottarapurāna does not justify the accurate meaning of the word padmakośa which denotes the internal portion of a lotus not the nails of a swan. The uses of this posture are not mentioned in the Viṣnudharmottarapurāna. But according to the Abhinayadarpana, this posture denotes some round shaped objects like breast of woman, ball, round cooking pot, egg and bell and the like. Moreover, this posture is used to show the blooming buds of flowers like marigold, lotus etc. Some kind of fruits like mango and wood apple are also portrayed with this hand posture ${ }^{[71]}$.

xiii) Uragaśírșa: The name of this posture itself identifies that the hand posture should look like the head of uraga i.e. a serpent ${ }^{[72]}$. In this posture the thumb should be clinching and the middle part should be hollow ${ }^{[73]}$. According to

${ }^{60}$ utkṣiptavakrā tu yadānāmikā sakanīyas̄̄/ asyaiva tu kapitthasya tatah syātkhațakāmukhaḥ// Vișnudharmottarapurāṇa, 3.26.31

${ }^{61}$ hotre chatragraha caiva karṣaṇe vyajane tathā/stragdāmadhāraṇe

kāryohyasan̉kocosyasamingrahah// Vișnudharmottarapurāna, 3.26.32

${ }^{62}$ kusumāvacaye muktāstragdāmnām dhāraṇe tathā/śaramadhyākarșaṇe ca

nāgallīpradānake/kasturikāivastūnām peșaṇe gandhavāane//

Abhinayadarpana, 125-126

${ }^{63}$ sūcī sìvanadravyaṁ/, p.361

${ }^{64}$ prasṭtā tarjanī cātra yadā sūcīmukhastadā / Viṣ̣nudharmottarapurāṇa,

3.26 .33

${ }^{65}$ nișpādane cābhinayennetraśakramaheśayoḥ/ Viṣnudharmottarapurāṇa,

3.26 .33

${ }^{66}$ V.S Apte, The student's Sanskrit English Dictionary, p.544

${ }^{67}$ Śabdakalpadruma, p.680

${ }^{68}$ Abhinayadarpana, 128-131

${ }^{69}$ padmasyeva kośo'bhyantaram vinatam yasyeti tathā/ Abhinavabhāratī,

Pushpendra Kumar (ed), Nātyaśāstra, Bharatmuṇi, Vol 1, p.356

${ }^{70}$ asyāngulyastu vipulāḥ sahāngușṭhena kuñcitāḥ/ urdhvāhamiansanakhasyaiva

sa bhavetpadmakośakah/Vișnudharmottarapurāna, 3.26.34

${ }^{71}$ Abhinayadarpana, 135-136

72 Śabdakalpadruma, p.231

73 ślișțongușțho nimnamadhyaḥ patākohiśiro bhavet/

Viṣnudharmottarapurāṇa, 3.26.35.
Abhinavagupta, this posture looks like the head of a snake and that is why this posture is named as uragaśīrșa ${ }^{\text {[74] }}$. According to the Viṣnudharmottarapurāna as well as the Abhinayadarpana this posture is used to show some activities like offering of water, giving information, sprinkling, nourishing and wrestling. Moreover, to establish the picture of a snake, this hand posture is used in Dance ${ }^{[75]}$.

xiv) Mrgaśirșa: The word mrgaśirșa is the union of two words viz., mrga and sirșa. The word mrga means deer ${ }^{[76]}$ and śirșa means head ${ }^{[77]}$. So, it can be said that the hand posture called mrgaśirșa identifies a posture which looks like the head of a deer. According to the Viṣnudharmottarapurāna, in mrgaśirșahasta, all the fingers are bent downwards and only the small finger goes upward ${ }^{[78]}$. In the Abhinayadarpana, the thumb is also suggested to be upward along with the little finger in sarpaśīsșahasta to make the mrgaśirșahasta. At this position the hand looks like a head of a dear with two horns. Abhinavagupta also keeps his view point in the same way and accepts mrgasírșahasta as a hand gesture which identifies the head of a deer with two horns ${ }^{[79]}$. This posture is used to denote piercing, cutting, and moving upward of the śakti weapon [ 80$]$. In the Abhinayadarpana, this posture is used to denote various things. This book states that- this posture is used to show woman, cheek, wheel, limit, terror, quarrel, attire, calling someone or the beloved, lute, feet massage, female organ, holding umbrella etc. ${ }^{[81]}$

xv) Kängūla: In kāngülahasta, the middle finger is set between the fore-finger and thumb while the ring finger is bent and the little finger is quite upward ${ }^{[82]}$. According to the Viṣnudharmottarapurāna this posture is used to denote fruits ${ }^{[83]}$. In the Abhinayadarpana, this posture is said to indicate things like fruits, bell, birds like cakora and cātaka, coconut etc. ${ }^{[84]}$

xvi) Kolapadma: In kolapadmahasta, beginning from the little finger other fingers are separately spread ${ }^{[85]}$. This hand posture is termed as alapadmahasta in the Abhinayadarpana ${ }^{[86]}$. In the Nātyaśāstra also it is known as alapadma ${ }^{\left[{ }^{[8]}\right.}$. In the Viṣnudharmottarapurāna, it is said that to say no, to denote void and non existence this

74 nimnam் talam் madhyasyābhimukhasya, sarpaśirastulyatvāt vāsyedam nāma/ Abhinavabhārat̄̄, Pushpendra Kumar (ed), Nātyaśāstra, Bharatmuṇi, Vol 1, p.356

${ }^{75}$ salilasya pradāne tu kāryā tena ca sūcanam/ Viṣnudharmottarapurāṇa, 3.26 .35

candane bhujage mandre prokṣaṇe poṣaṇādiṣu/ devasyodakadāneṣu āsphāle gajakumbhayoḥ/ bhujasthāne mallānām tu yujyate sarpaśīrșakaḥ/ Abhinayadarpana, 138-139

${ }^{76}$ V.S Apte, The student's Sanskrit English Dictionary, p.445

77 V.S Apte, The student's Sanskrit English Dictionary, p.557

${ }^{78}$ kanișțānguṣṭhakā cordhvā tadā syānmṛasśīṣakaḥ/

Vișnudharmottarapurāna, 3.26.36

${ }^{79}$ mrgaśīrșakamāha mrgasyeva śirasthe śrnge yasya/ Abhinavabhāratī,

Pushpendra Kumar (ed), Nātyaśāstra, Bharatmuṇi, Vol 1, p.357

${ }^{80}$ sūcite cchedite kāryaṁ śaktyā svoccālane tathā/ Viṣnudharmottarapurāṇa,

3.26 .37

${ }^{81}$ Abhinayadarpaṇa, 140-141

82 tretāgnisamsthitā madhyā tarjanyaṅgușțhayoryadā/ kāṅgule nāmikā vakrā cordhvā kan̄yasī/ Viṣnudharmottarapurạṇa, 3.26.37-38

${ }^{83}$ anena khalu kartavyaṁ phalānām tu nirūpaṇami/ Viṣnudharmottarapurāṇa, 3.26 .38

${ }^{84}$ lakucasya phale ghaṇṭikārthake / cakore cātake nārikele ca kāñgulo yujyate karah/ Abhinayadarpaṇa,144-145

${ }^{85}$ āvartyante karatale yasyānulaḥ karasya vai/ pārśvāgatavikīrṇāśca

kolapadma iti smṛtaḥ/ Viṣnudharmottarapurāṇa, 3.26.39

${ }^{86}$ kaniṣthāàā vakritāśca viralāścāapadmakaḥ/ Abhinayadarpaṇa,146.

${ }^{87}$ Nátyaśástra, 9.6 
hand posture is used. In the Nātyaśāstra, this posture is suggestive of indicating prevention, sense of the sentences like "of whom are you" and "It is not". Moreover, in case of a women's reference of herself, this hand gesture has been used ${ }^{[88]}$.

xvii) Catura: In catura, the middle finger remains vertical, the thumb should be kept in the middle and the rest of the fingers are stretched out ${ }^{[89]}$. According to the Viṣnudharmottarapurāna, some colours are pointed with this hand gesture. When the hand is raised in catura posture, it denotes white colour. When the hand moves circular and semi-circular motion in caturahasta, it denotes yellow and red colour respectively. In compacted form it shows blue colour. When the hand is kept in normal position with caturahasta it denotes black and the other remaining colours ${ }^{[90]}$. Instead of showing colours, in the Abhinayadarpana this posture denotes some metals like gold, copper and iron. This posture also shows the application of some greasy substances like oil, ghee etc on the face ${ }^{[91]}$.

xviii) Bhramara: The name of the posture bhramara itself identifies the shape of a bhramara i.e. black bee ${ }^{[92]}$. Abhinavagupta also admits it [93]. According to the Viṣnudharmottarapurāna, in the bhramarahasta, the tip of the fore-finger and the thumb should be joined together. Then middle finger is curved and the rest of the fingers are separately raised ${ }^{[94]}$. This posture is used to show the position of holding of a lotus. The acting of putting ear-rings is also done with this hand gesture ${ }^{[95]}$. In the Abhinayadarpana, this posture is said to denote bee, parrot, wing, crane, cuckoo etc. ${ }^{[96]}$

xix) Hamsavaktra: The word hamsavaktra is the union of two words viz. hamsa and vaktra. Hamsa means swan ${ }^{[97]}$ and vaktra means mouth [98]. So, the word hamsavaktra denotes the mouth or beak of a swan. It is worth mentioning that. In the Viṣnudharmottarapurāna the term hamsavaktra is used where as in the Abhinayadarpana the term hamsasya is used to denote this hand gesture. According to the Viṣnudharmottarapurāna in hamsavaktrahasta, except the ring and little fingers, all the three fingers of the hand are placed together without any interspace. In this posture, the ring finger and the little finger are kept spread [99]. But According to the Abhinayadarpana, the tip of the thumb and the forefinger are placed together and rest fingers should be

\footnotetext{
${ }^{88}$ pratiședhakṛte yojyaḥ kasya tvannāsti śūnyavacaneșu/ punarātmopanyāsaḥ strīṇāmetena kartavyạ̣/ Nātyaśāstra, 9.91

${ }^{89}$ tisraḥ prasāritāngulyastathā cordhvā kanīyas̄i// tasyā madhyāśritongușṭhaḥ

karah sa caturaḥ smṛtaḥ/ Viṣnudharmottarapurāṇa, 3.26.40-41

${ }^{90}$ ūrdhvasthe ca nave śvetam rakte syādardhamaṇụalam்/ maṇḍalam na

bhavetpītam் nīlam ca mṛditam bhavet/ svabhāvasthena kṛtsnam் ca śeșā

varṇāstathaiva ca//Viṣnudharmottarapurāṇa, 3.26.42-43

${ }^{91}$ kastūryām kiñcidarthe ca svarṇe tāmre ca lohake/ ānane ghṛtatailādau

yujyate caturah karahı// Abhinayadarpana, 150-152

${ }_{92}$ V.S Apte, The student's Sanskrit English Dictionary, p.414

${ }^{93}$ tadākṛtitvādbhramaro hastaḥ/ Abhinavabhāratī, Pushpendra Kumar (ed),

Nātyaśāstra, Bharatmuni, Vol 1, p.359

${ }^{94}$ madhyamāñgușṭhasandeśo vakrā caiva pradeśinī/ ūrdhvamanyāh

prakīrṇāśca bhramaraśca tadā bhavet/ Viṣnudharmottarapurāṇa, 3.26.44

${ }_{95}$ padmādigrahaṇe kāryam karṇapūre tathāpyayam/ Viṣnudharmottarapurāna,

3.26 .45

${ }^{96}$ bhramare ca śuke pakṣe sāase kokilādiṣu/bhramarākhyaśca hasto’yam.....// Abhinayadarpana, 153

${ }^{97}$ hamısạ̣... pakșiviśeșah / hāsa iti bhāṣā/ Śabdakalpadruma, p.466

${ }^{98}$ vaktram mukham/ $\dot{S} a \dot{b} d a k a l p a d r u m a$, Part 3, p.242

${ }^{99}$ tarjanīmadhyamāngușțhā tretāgnisthā nirantaram/bhaveyurhamaavaktrasya śeșā hyanyāḥ prasāritāḥ/ Viṣnudharmottarapurāṇa, 3.26.45-46
}

spread in this hand posture ${ }^{[100]}$. This posture is used to show some qualities like slimness, lightness, weakness and softness ${ }^{[101]}$.

xx) Hamsapaksa: The word hamsapakșa consists of two words viz. hamsa and pakșa. The word hamsa is already explained in the context of hamsavaktrahasta. It means swan. The word pakșa means wings ${ }^{[102]}$. So the word hamsapaksa denotes the wings of a swan. In the Viṣnudharmottarapurāna, this hand posture is described as one where the little finger is lifted crookedly and the thumb is bent ${ }^{[103]}$. In the Abhinayadarpana, when the hamsapakșahasta is done, the hand is instructed to keep in sarpaśî́șamudrā ${ }^{[104]}$. The remaining instructions are same with the Viṣnudharmottarapurāna. According to the Viṣnudharmottarapurāna some activities like touching, anointing and shampooing are denoted through this hastamudrā. According to the Abhinayadarpana, the number six is denoted by this posture. Some activities like building of a bridge, putting nail marks and covering something are also indicated through this hand posture [105].

xxi) Sandaimśa: The word sandamía means kankamukhah ${ }^{[106]}$ i.e. a pair of tong ${ }^{[107]}$. Tong is a kind of tool which is used to hold something. According to the Viṣnudharmottarapurāna, when the tip of the fore-finger and the thumb are pressed together like the mouth of a tong and the middle portion of the palm is curved in arālahasta, this posture is called sandainśahasta [108]. This hand posture involves the closing and opening of fingers. It is of three kinds viz., agraja, mukhaja and pārśvakrta ${ }^{[109]}$. The agraja sandamínhasta is used for holding and extraction of thorns or splinters. The mukhaja is used to show the activity of plucking flowers. There are many uses of pārśvakrta type of sandamśahasta. These are- colouring of picture, pressing of breast, showing of head etc. ${ }^{[110]}$ According to the Abhinayadarpana, sandamśahasta is used to show the action of the offering something to gods. The belly portion is also indicated with this hand posture. Besides, this posture is used to indicate something like injury, worm, terror, and number five ${ }^{[111]}$.

xxii) Mukula: The term mukula has been defined clearly in the Śabdakalpadruma. It is said that when the state of bud is discarded i.e. when the blooming starts, it refers

\footnotetext{
100 madhyamādyāstrayongulyaḥ prașrtā viralā yadi/ tarjanyangușțhasamíśleșāt karo haṁāsyako bhavet/ Abhinayadarpaṇa, 154

101 ślakṣnnalāghavanị̣ sāramārdaveșu prayojayet/ Viṣnudharmottarapurāṇa, 3.26 .46

${ }^{102}$ pakṣiṇāmavayavavișeśaḥ/ pākhā iti bhāṣa, Śabdakalpadruma, Part 3, p.2 103 tiryak piṇ ḍikrtā yasminunnatā ca kanișțhikā/añgușṭhah kuñcitastvevam hamsapakṣa iti smṛtaḥ/ Viṣnudharmottarapurāṇa, 3.26.47

${ }^{104}$ sarpaśirșakare samyak kanișțhā praș̣tā yadi/ hamsapakṣạ̣ karaḥ so’yam tannirūpanamucyate/ Abhinayadarpana, 157

${ }^{105}$ șatsamikhyāyām setubandhe nakharekhānkaṇe tathā/pidhāne ham்sapakṣo'yam kathito bharatāgame/ Abhinayadarpaṇa, 158

${ }^{106}$ sandamśaḥ kañkamukhaḥ/ Śabdakalpadruma, p.236

${ }^{107}$ V.S Apte, The student's Sanskrit English Dictionary, p.127

108 tarjanyaṅgușțhasamidamíśastvarālasya yadā bhavet/

nirbhugnatalamadhyaśca sasandamiśa iti smṛtạ̣/ Viṣnudharmottarapurāna, 3.26.49

${ }^{109}$ sandamíśastrividho jñeyastvagrajo mukhajastathā/ tathā pārśvakṛtaścaiva tasya karmāṇi me śṛ̣u/ Viṣnudharmottarapurāṇa, 3.26.50

${ }_{110}$ sandamiśagrahane kāryah śalyoddhāre tathāgrajah/ ālekhārañjane caiva tarjanīpīụane tathā/ pārśvasthah śirạ̣ samdarśane tathā/ Viṣnudharmottarapurāṇa, 26.41-42

${ }^{111}$ udare validāne ca vraṇe kịte mahābhaye/ arcane pañcasamikhyāyām sandaṁ́áăkyo niyujyate/ Abhinayadarpaṇa,160
} 
to mukula ${ }^{[12]}$. Thus when the bud starts to bloom, it is termed as mukula. The Viṣnudharmottarapurāna suggests that the tips of all fingers should be joined together to make this posture ${ }^{[113]}$. When the tips of all fingers are joined together, it makes a shape of a booming bud. Thus, it justifies the name of this posture. Abhinavagupta also gives his view in the same way ${ }^{[114]}$. This posture is formed to show the activities like worshiping of deities and offering oblations. Moreover, to show the lotus flower this hand posture is suggested in dance performance in the Viṣnudharmottarapurāna [115]. In the Abhinayadarpana, this posture is suggested to be used to denote flowers like water lily and the flower of kadali i.e. Banana ${ }^{[116]}$. The holding of five arrows by kāmadeva and signet or seal are also identified through this hand posture. The action of eating is also shown with this hand posture ${ }^{[117]}$.

\section{Conclusion}

Thus it appears that single hand postures play a great role in performing arts. They not only suggest some objects, but also denote some specific actions in performance. Thus these postures can convey the message of the writer to the spectators through the performers. It is also important to note that the Viṣnudharmottarapurāna and the Abhinayadarpaña have given specific views about these forms and gestures used in performing arts. In most cases the two sources convey similar ideas although they bear differences in some points. The differences may be due to amalgamation of new ideas or adaptations from other sources. Even in modern time, most of these asamyuktahastas are used in classical dance forms to convey the traditional ideas.

\section{References}

1. Abhinayadarpaṇa. Nandīkeśvara, Gosh. Manomohan, Firma K.L. Mukhopadhyay, Calcutta, $2^{\text {nd }}$ ed. 1957.

2. Daśarūpaka, Dhanañjaya, Acharya Nrayanaram, Nirnaya sagar press, Bombay, $5^{\text {th }}$ edn., 1949.

3. Kāmasūtra, Vātsyāyana, Shastri. Goswami Damodar, Chowkhamba Sanskrit Series office, Banares, 1929.

4. Nātyaśāstra, Bharatmuni, with commentary of Abhinavabhārat̄̄, Vol-1, Ghosh. M.M (eng. Trans), Kumar. Pushpendra (ed.), New Bharatiya book corporation, Delhi, $1^{\text {st }}$ ed. 2006.

5. Nātyaśāstra, Bharatmuni, with commentary of Abhinavabhāratī, Ghosh. M.M(eng. Trans), Kumar. Pushpendra (ed.), New Bharatiya book corporation, Delhi, $1^{\text {st }}$ ed. 2006, 2.

6. Śrivișnudharmottarapurāna, Third Khanda, with English trans, Dr. Shah. Priyabala, Parimal publication, $1^{\text {st }}$ end. 2002.

7. The Viṣnudharmottara, part IIIA, Treatise on Indian Painting and Image Making- Primary source edition, Kramrisch. Stella, Calcutta University Press, 1928.

\footnotetext{
112 mukulaḥ muñcati kalikātvam / 1̄ṣad vikasitakalikā, Śabdakalpadruma, p.726

${ }^{113}$ samāgatāgrānguliko muktalạ̣ padmakośakaḥ/ Viṣnudharmottarapurāna,

3.26 .52

${ }^{114}$ mukulākāratvānmukulạ̣/ Abhinavabhāratī, Pushpendra Kumar (ed),

Nātyaśāstra, Bharatmuni, Vol 1, p.362

115 devārcākaraṇe kāryo balo padmanirūpaṇe/ Viṣnudharmottarapurāṇa,

3.26 .53

${ }^{116}$ M. Monier Williams, A Sanskrit- English Dictionary, p.248

${ }^{117}$ bhojane pañcabāṇe mudrādidhāraṇe/ nābhau ca kadalīpuṣpe yujyate mukulaḥ karaḥ/ Abhinayadarpaṇa,162-163
}

8. Viṣnudharmottaramahāpurāṇam, Tṛtīyakhaṇụa, with Hindi trans, Narayana. Kapildeva, Chowkhamba Sanskrit Series office, Varanasi, $1^{\text {st }}$ ed., 2015.

\section{Modern works}

1. Agrawala S. Vasudeva The Heritage of Indian Art, Publications divisions, Ministry of information and broadcasting, 1964.

\section{Dictionaries}

1. Amarakośa, Amarasimha, Abhimanyu. Manna Lal, Master khelarilal \& sons, Banaras, 1937.

2. Apte, V.S, The student's Sanskrit English Dictionary, Motilal Banarsidass Publishers, Delhi, $13^{\text {th }}$ reprint, 2012

3. Macdonell. Arthur A; A Sanskrit English Dictionary, Oxford, 1893.

4. Śabdakalpadruma, Raja Radha Kanta Deva, Part- 1, 2 and 3, Chowkhamba Sanskrit Series Office, Varanasi- 1.

5. Williams M. Monier, A Sanskrit- English Dictionary, Vol-1, Parimal Publications, Delhi, $3^{\text {rd }}$ reprint, 2018. 